\title{
Effects of neonatal administration of the reversible goitrogen propylthiouracil on the testis interstitium in adult rats
}

\author{
S. M. L. C. Mendis-Handagama ${ }^{\mathrm{T}}$ and O. P. Sharma ${ }^{2}$ \\ ${ }^{1}$ Department of Animal Science, College of Veterinary Medicine, The University of Tennessee, \\ Knoxville, TN 37996 USA; and ${ }^{2}$ Department of Medicine, University of Virginia Health \\ Science Center, Charlottesville, VA 22908, USA
}

\begin{abstract}
The effects of neonatal treatment with the reversible goitrogen, 6-n-propyl-2-thiouracil (PTU) on the volumes of testicular interstitial components, the number and average volume of Leydig cells, and the steroid secretory capacity of testis and Leydig cells of rats at 135 days of age were investigated. Rat pups were hypothyroid from birth to 25 days of age following the addition of $0.1 \%(w / v)$ PTU to the drinking water of the mother. Treatment was stopped at 25 days and the pups subsequently returned to a euthyroid state. Control rat pups were raised without adding PTU to drinking water of the mother. On day 135, one testis from each rat ( $n=5$ per group) was fixed by whole body perfusion for microscopy and stereology, and the ipsilateral testis was used for steroid secretion analysis using an in vitro testis perfusion system. Average testis volume was $84 \%$ greater in PTU-treated rats than in controls. This increase resulted from increases in both the seminiferous tubule $(86 \%)$ and the interstitial $(80 \%)$ volumes. Moreover, absolute volumes of all testis components in PTU-treated rats were significantly $(P<0.05)$ greater than those of controls; the highest volume increase was observed in the lymphatic space (147\%). The number of Leydig cells per testis was nearly doubled, but the average volume of a Leydig cell was decreased by $25 \%$ in PTU-treated rats compared with controls. Steroid secretion per testis was not significantly different between control and PTU-treated rats; however, steroid secretion per Leydig cell was significantly lower in PTU-treated rats than in controls. These results demonstrate that the neonatal administration of PTU causes Leydig cell hyperplasia. However, the normal androgenic status of these animals is maintained by hypotrophy associated with reduced steroid secretion of individual Leydig cells at maturity.
\end{abstract}

\section{Introduction}

A deficiency of thyroid hormone during neonatal-prepubertal life increases adult testicular size and sperm production in rats (Cooke and Meisami, 1991; Cook et al., 1991; Kirby et al, 1992). Studies have associated these changes with an increase in the number of Sertoli and germ cells (Van Haaster et al., 1992; Hess et al., 1993). In achieving this unprecedented increase in spermatogenic capacity by treating with the reversible goitrogen, 6-n-propyl-2-thiouracil (PTU), changes have also been observed in the hormonal profiles during testicular development and adulthood (Kirby et al., 1992). However, the effect of transient thyroid hormone deficiency during neonatalprepubertal life on the components of the testis interstitium in general, and Leydig cells in particular, at maturity has not been investigated.

It is logical to hypothesize that the increased testis size and sperm production in these adult PTU-treated rats could be associated with increased volumes of components of the testis

Received 24 February 1993 interstitium including the volume of Leydig cells, which could be achieved via hypertrophy or hyperplasia or both mechanisms. If Leydig cell volume is increased in PTU-treated rats, an increase in circulating testosterone concentrations would be expected. However, the circulating concentrations of testosterone are similar in both control and PTU-treated rats (Cooke and Meisami, 1991; Kirby et al., 1992). Testosterone production by Leydig cells depends on LH. However, serum concentrations of LH are significantly lower in PTU-treated rats than in controls at adult ages (Kirby et al., 1992). The circulating concentrations of androgens would be maintained in the presence of low concentrations of circulating LH by alterations in the structure or function of Leydig cells in the PTU-treated rats.

This study was designed to investigate the effects of transient neonatal hypothyroidism, induced by PTU treatment, on the structure and function of the testis interstitium in adult rats. The volume changes in the testis interstitium and its components were determined, together with Leydig cell number, average volume and steroid secretory capacity in adult PTU-treated rats. 


\section{Materials and Methods}

\section{Animals and treatments}

Sprague-Dawley rats derived from parental stock purchased from Harlan (Indianapolis) were bred and maintained as described by Cooke and Meisami (1991) and Cooke et al. (1992). After birth, the sex of pups was determined and they were weighed. Only male pups were used in the study, and litter size was adjusted to 6-8. Pups were weighed every week and maintained in accordance with the NIH Guide for the Care and Use of Laboratory Animals.

Certain litters were randomly designated as controls; control mothers and their pups were untreated and received food and water ad libitum. For treated litters, 0.1\% (w/v) PTU (Sigma, St Louis, MO) was added to the mother's water beginning immediately after birth. PTU ingested by the mother is transferred to the pups through the milk, resulting in hypothyroidism in the pups (Kirby et al., 1992). The 0.1\% PTU used in the present experiments is sufficient to suppress thyroxine maximally during the treatment period (Kirby et al., 1992) and leads to maximal increases in adult testis size (Cooke and Meisami, 1991; Cooke et al., 1993).

For treated litters, food and PTU-containing water were offered ad libitum. PTU has a bitter taste, so diet cherry Kool-Aid was added to the PTU-containing water to increase palatability (Cooke and Meisami, 1991). Maternal water consumption by PTU-treated dams was monitored daily from birth of pups to day 25 to ensure adequate maternal water consumption and to prevent dehydration of the dam and pups. At 25 days of age, PTU treatment was stopped and pups were weaned and housed 3-4 per cage. Pups of both control and treated groups were given tap water and food ad libitum. Rats were killed by an overdose of inhalation of ether on day 135 .

\section{Tissue preparation}

At 135 days of age, one testis-epididymis was removed from each control and PTU-treated rat ( $n=5$ group), and placed in ice-cold 0.25 mol sucrose $1^{-1}$. The epididymis was dissected from the testis, the testis was weighed and the fresh testis volume was calculated as described by MendisHandagama and Ewing (1990) and Mendis-Handagama (1992). This testis was then used to determine testosterone secretion under the in vitro perfusion conditions described subsequently.

The ipsilateral testis of each rat was fixed and processed for microscopy and morphometry as described by MendisHandagama and Ewing (1990) and Mendis-Handagama (1992), using a fixative containing $2.5 \%$ glutaraldehyde in $0.1 \mathrm{~mol}$ cacodylate buffer $1^{-1}$ (pH 7.4).

\section{Microscopy and morphometry}

Sections of $1 \mu \mathrm{m}$ were made from the blocks of polymerized testis tissue and were stained with modified methylene blueazure II stain (Dawes, 1980). These sections were viewed under an Olympus BH-2 photomicroscope at $\times 40$ and $\times 100$. Volumes of various testis components, including the seminiferous tubules, interstitium, Leydig cells, blood vessels, lymphatic space, macrophages and connective tissue cells (i.e. endothelial cells, fibroblasts, peritubular myoid cells and pericytes) were determined as described by Mendis-Handagama et al. (1988). In brief the volume density of each testis component $\left(V_{v}\right.$; defined as the volume of each component per unit testis volume) was determined by point counting using an ocular test grid containing 121 test points fitted to the eye piece of the above microscope. The volume of each testis component per testis $(V)$ was calculated by multiplying the volume density by the volume of the testis $\left(V_{T}\right)$.

$$
V=\left(V_{v}\right) \times\left(V_{T}\right)
$$

The numerical density of Leydig cells ( $N_{v}$; defined as the number per unit volume of testis) in control and PTU-treated rats was determined by using the disector method (Sterio, 1984) as described by Mendis-Handagama and Ewing (1990), Mendis-Handagama et al. (1990a) and Mendis-Handagama (1992). The number of Leydig cells per testis $(N)$ was obtained by multiplying the numerical density of Leydig cells by the volume of testis.

$$
N=\left(N_{v}\right) \times\left(V_{T}\right)
$$

The average volume of a Leydig cell $\left(V_{L C}\right)$ was calculated by dividing the volume density of Leydig cells $\left(V_{v L C}\right)$ by the numerical density of Leydig cells $\left(N_{v L C}\right)$.

$$
V_{L C}=V_{v L C} d N_{v L C}
$$

\section{In vitro perfusion of testis and assay of steroids}

Both control and PTU-treated testes were perfused in vitro with artificial medium containing ovine $\mathrm{LH}\left(100 \mathrm{ng} \mathrm{ml}^{-1}\right)$ as described by VanDemark and Ewing (1963) and Ewing et al. (1975). Testicular venous effluent was collected for $4 \mathrm{~h}$ to measure the following testicular steroids: testosterone, androstenedione, $17 \alpha$-hydroxyprogesterone and progesterone. Steroid secretory capacity per Leydig cell was calculated by dividing the amount of steroid secreted per testis by the number of Leydig cells per testis as described by MendisHandagama et al. (1988).

A Waters Associates Model 6000A pump, U6K injector, $30 \mathrm{~cm} \times 3.9 \mathrm{~mm}$ i.d. Bondapak $\mathrm{C}_{18}$ column (Waters Assoc. Milford, MA) and a $7.0 \mathrm{~cm} \times 2.0 \mathrm{~mm}$ i.d. Whatman CO:PELL ODS precolumn (Whatman, Clifton, NJ) were used for the chromatography. Detection of $\Delta^{4}$-3-ketosteroids was accomplished by monitoring absorbance at $240 \mathrm{~nm}$ with a Spectroflow Model 770 UV analyser (Schoeffel, Westwood, NJ). Peak areas were estimated by a Spectra-Physics (Stirling, NJ) which also carried out the post-run calculations for mass estimation. The HPLC solvents used were tetrahydrofuran and methanol (Photrex grade; T. J. Baker, Phillipsburgh, NJ). Mixtures of the HPLC solvents with double glass distilled water were filtered vigorously stirred and vacuum degassed for at least $\mathrm{I} h$ before use.

The separation and measurement of testosterone, androstenedione, 17 $\alpha$-hydroxyprogesterone and progesterone in venous effluents from in vitro perfused rat testes were performed by isocratic high-performance liquid chromatography 

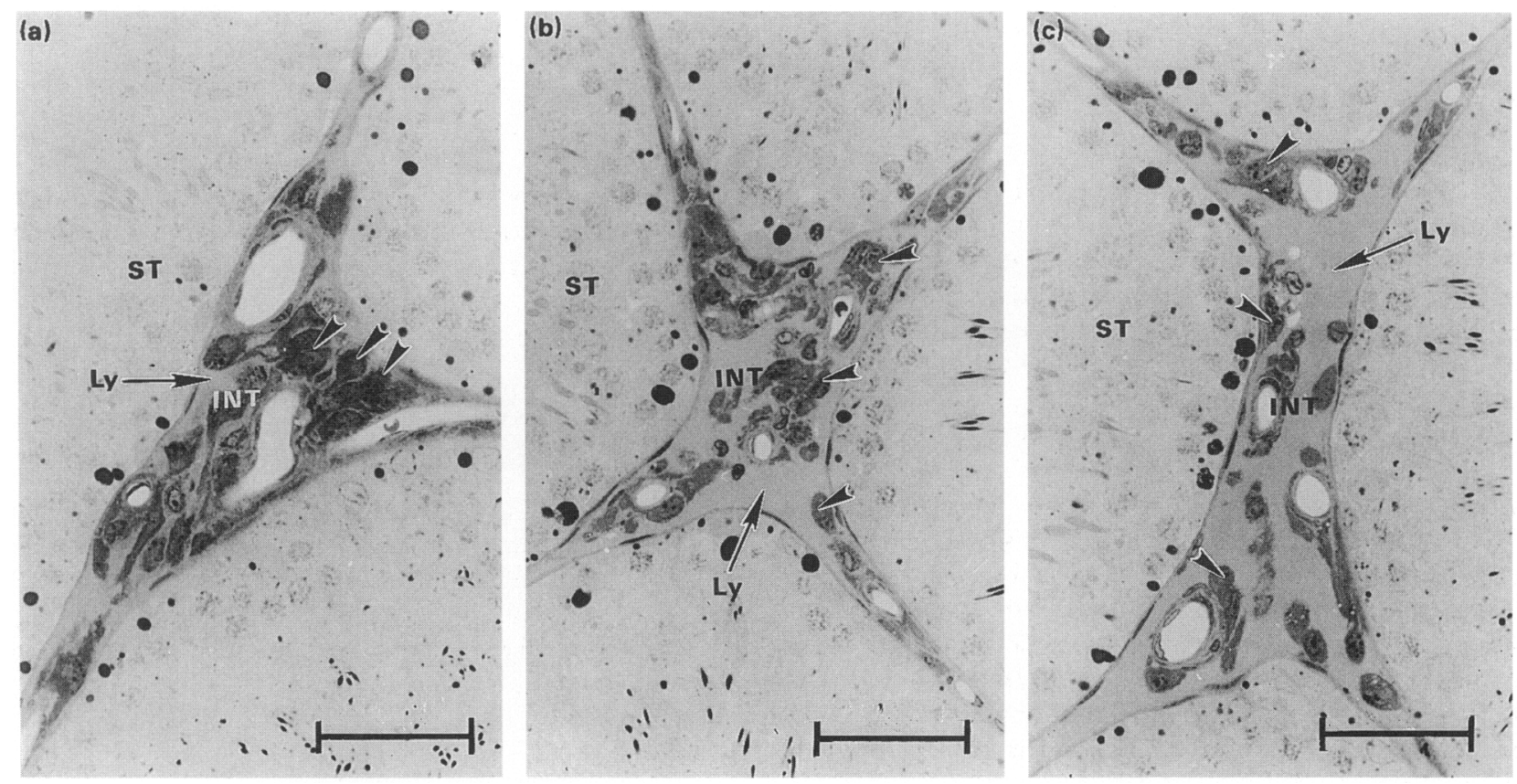

Fig. 1. Low power photomicrographs of the testis interstitium (INT) of (a) control and (b and c) propylthiouracil (PTU)-treated rats. Leydig cells (arrowheads) are the most abundant cell type in the testis interstitium. Lymphatic space (Ly) was increased after PTU treatment as shown in (b) and (c). ST: seminiferous tubule. Bar represents $50 \mu \mathrm{m}$.

(HPLC) with on-line ultraviolet (UV) absorbance detection (at $240 \mathrm{~nm}$ ) method as described by Cochran et al. (1979). Nonradioactive $11 \beta$-hydroxyandrostenedione was used as an internal standard. Prepared samples with internal standard were injected into the chromatograph and eluted with tetrahydrofuran:methanol:water (16:28:56, v:v:v). The sensitivity of the assay was $10 \mathrm{ng}$ for testosterone, androstenedione and $17 \alpha$ hydroxyprogesterone and $25 \mathrm{ng}$ for progesterone. All of the samples were run in one assay. The intra-assay coefficient of variation was $3.2 \%$.

\section{Statistical analysis}

Differences between the means were compared using Student's $t$ test. Data were expressed as mean (SEM). Differences were considered significant when $P<0.05$.

\section{Results}

\section{Histology}

The perfusion-fixed testicular tissue was well preserved and suitable for morphometric analysis. Tissue relationships were well maintained at the light microscope level (Figs 1,2), and also at the electron microscope level (results not shown).

In control rats, testicular interstitial tissue contained prominent clusters of Leydig cells often surrounding blood vessels or occupying positions more centrally placed within the interstitial tissue (Figs 1a and 2a). Leydig cells exhibited a variety of shapes including circular, ovoid or irregularly elongated profiles. Leydig cell cytoplasm was densely stained because it contained many inclusion bodies, which represented mitochondria. This characteristic staining property of Leydig cells was useful in distinguishing Leydig cells from other types of cell in the interstitium of the testis, especially in instances when cytoplasmic fragments of Leydig cell profiles were present without a nucleus. Moreover, cytoplasmic lipid inclusions were not commonly noted in these Leydig cells. The nuclei of these Leydig cells, when present, frequently contained a prominent nucleolus and dense patches of heterochromatin associated with the nuclear membrane. There were fewer macrophages than Leydig cells, and macrophages were readily identified and distinguished from all other cells including Leydig cells, by their pale-staining cytoplasm which contained many cytoplasmic granules and vesicles, indicative of their well-developed lysosomal components associated with the phagocytic function of these cells (Fig. 2). Endothelial cells of blood vessels and lymphatics, fibroblasts, peritubular myoid cells, and pericytes associated with capillaries were collectively identified and quantified as connective tissue cells. A representative testis interstitial area from a control rat is shown (Fig. 1a) and a higher magnification of the same area of the interstitium is presented (Fig. 2a) to demonstrate the various interstitial components quantified.

The basic morphology of the testis interstitium in PTUtreated rats appeared normal, except for the pronounced enlargement of lymphatic space (Figs $1 b, c ; 2 a$ and 3 ). The mature Leydig cells present in the testis interstitium were similar in morphology to those described for the control rats. However, in PTU-treated rats, Leydig cell profiles in section were smaller than those in controls (Figs I and 2). In addition to mature Leydig cells, small numbers of immature Leydig cells were also observed in the testis interstitium of PTU-treated 

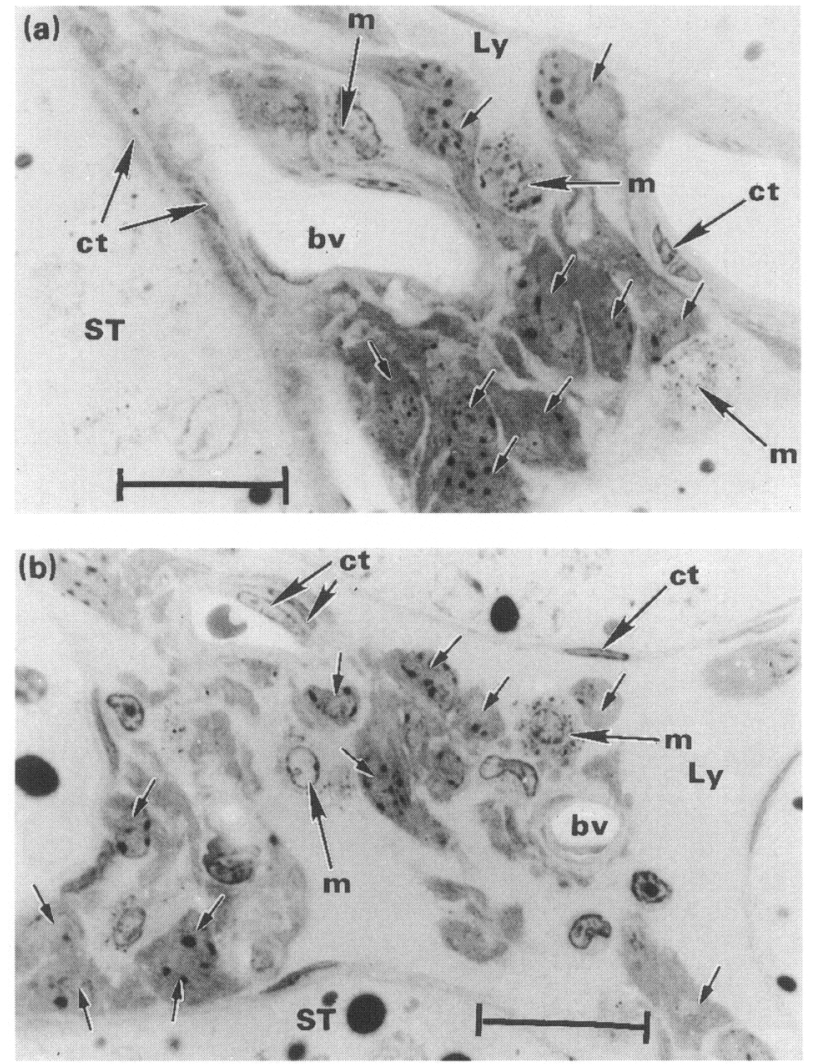

Fig. 2. Higher power photomicrograph of the testis interstitium shown in Fig. I(a) (control) and (b) (propylthiouracil (PTU)-treated rats). Arrows without labels depict Leydig cells. Note that the Leydig cell profiles are smaller in PTU-treated group compared with controls. $\mathrm{m}$ : macrophages, ct: connective tissue cells; bv: blood vessels, Ly: lymphatic space; ST: seminiferous tubules. Bar represents $20 \mu \mathrm{m}$.

rats (Fig. 3). By comparison with adult/mature Leydig cells of both control and PTU-treated rats, these immature Leydig cells exhibited a very different morphology and were similar in morphology to Leydig cells in the fetal/neonatal testis (Lording and de Kretser, 1972; Mendis-Handagama et al., 1987). The most distinct feature was the presence of an abundant supply of cytoplasmic lipid droplets (Lording and de Kretser, 1972; Mendis-Handagama et al., 1987; Fig. 3), a feature not commonly observed in the adult rat Leydig cells. The shapes of these immature Leydig cells varied; elongated, ovoid and circular profiles were observed. These immature Leydig cells were frequently observed in association with the peritubular tissue (Fig. 3).

The morphology and location of macrophages were similar in control and PTU-treated rats. Moreover, connective tissue cells in the testis interstitium of PTU-treated rats showed no difference from those in control testes.

\section{Morphometry}

Average fresh testis volume in control and PTU-treated rats was $1970 \mathrm{~mm}^{3}$ (SEM $\left.=110\right)$ and $3630 \mathrm{~mm}^{3}$ (SEM = 275), respectively, corresponding to an $84 \%$ increase in volume compared with controls. The absolute volumes of seminiferous
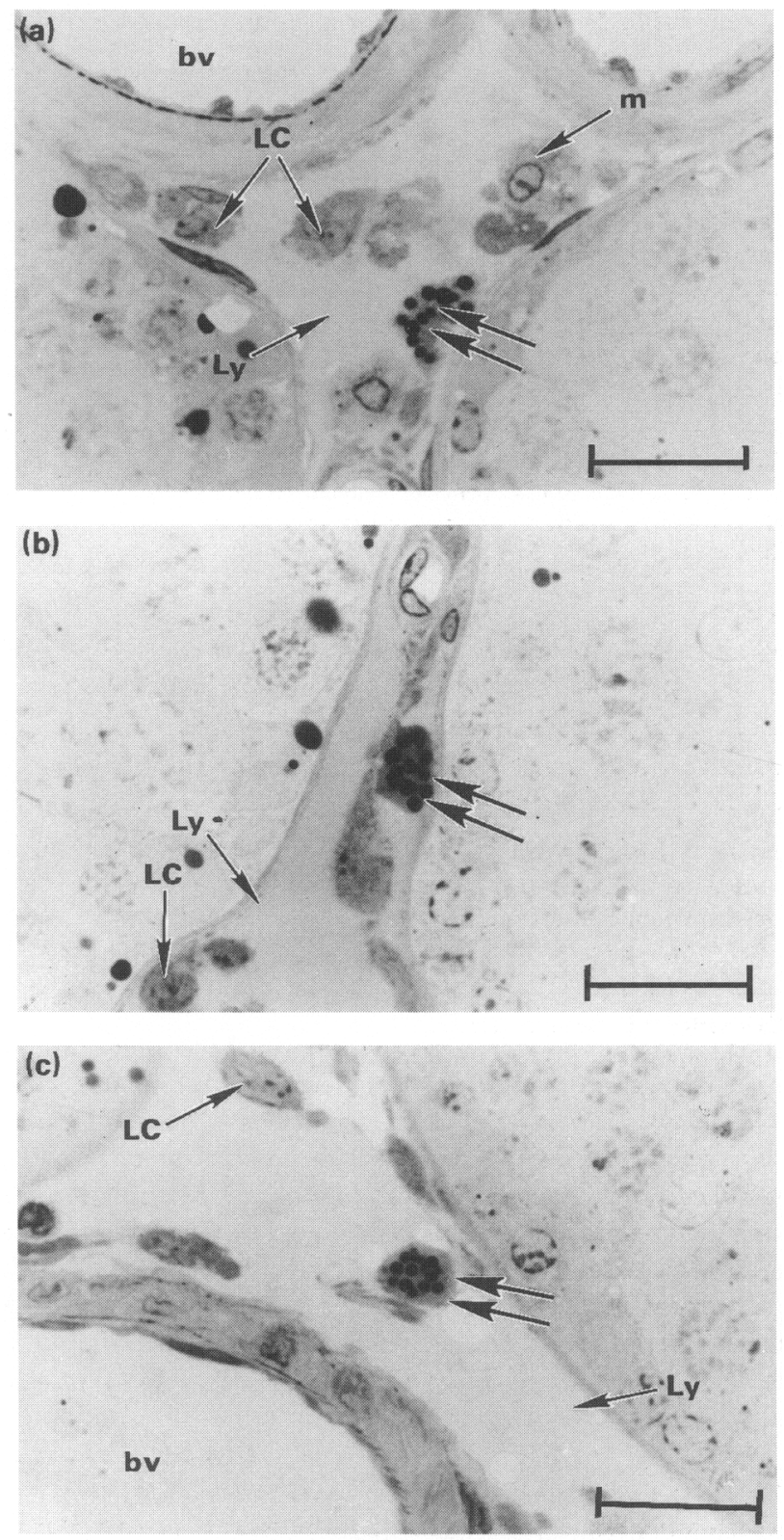

Fig. 3. Immature Leydig cells (double arrows) in the testis interstitium of propylthiouracil (PTU)-treated rats. Their cytoplasm is abundant with lipid droplets, a feature not observed in adult Leydig cells of rats. Note that in (a) the shape of the cell is somewhat elongated. Moreover, these immature cells are frequently located adjacent to the peritubular tissue. LC: Leydig cells, Ly: lymphatic space, bv: blood vessels, m: macrophages. Bar represents $20 \mu \mathrm{m}$.

tubules, testis interstitium, Leydig cells, blood vessels, lymphatic space and connective tissue cells were significantly greater in PTU-treated rats than in controls (Table 1). By contrast, the absolute volume of macrophages was not significantly different between control and PTU-treated rats (Table 1). The percentage volume increases of the tubular compartment (i.e. seminiferous tubules) and intertubular compartments (i.e. interstitium) were 80 and $86 \%$, respectively. These increases in volume percentages are similar to the percentage increase in testis volume (84\%) after PTU treatment. However, 
Table 1. Absolute volumes of testis components in 135-day-old control and propylthiouracil (PTU) treated rats

\begin{tabular}{lrrr}
\hline Tissue & Control $\left(\mathrm{mm}^{3}\right)$ & PTU-treated ${ }^{\mathrm{a}}\left(\mathrm{mm}^{3}\right)$ & Increase in volume $(\%)$ in PTU-treated rats \\
\hline Seminiferous tubules & $1776(88)$ & $3198(228)^{*}$ & 80 \\
Interstitium & $206(21)$ & $383(31)^{*}$ & 86 \\
Leydig cells & $44(4)$ & $61 \quad(6)^{*}$ & 39 \\
Blood vessels (lumen) & $30(4)$ & $49(8)^{*}$ & 63 \\
Lymph & $81(6)$ & $200(21)^{*}$ & 147 \\
Connective tissue cells & $46(3)$ & $67(4)^{*}$ & 46 \\
Macrophages & $5(0.9)$ & $7.7)$ & 40 \\
\hline
\end{tabular}

aPTU-treated from birth to 25 days.

${ }^{b}$ Fibroblasts, endothelial cells, peritubular myoid cells, pericytes.

Data are shown as mean (SEM), and $n=5$ rats per group.

* Significant differences between treatment groups $(P<0.05)$.

Table 2. Number of Leydig cells and average volume in control and propylthiouracil (PTU) treated rats at 135 days

\begin{tabular}{lcr}
\hline Parameter & Control & PTU-treated \\
\hline $\begin{array}{l}\text { Number of Leydig cells } \\
\text { per testis }\left(\times 10^{6}\right)\end{array}$ & $26(2)$ & $50(5)^{*}$ \\
$\begin{array}{l}\text { Average volume of a Leydig } \\
\text { cell }\left(\mu \mathrm{m}^{3}\right)\end{array}$ & $1642(28)$ & $1228(11)^{*}$ \\
\hline
\end{tabular}

aPTU-treated from birth to 25 days.

Data are shown as mean (SEM), and $n=5$ rats per group.

*Significant differences between treatment groups $(P<0.05)$.

the percentage volume increases of components of the testis interstitium were different among components (Table 1 ), the greatest increase (147\%) occurring in the lymphatic space.

The mean number of Leydig cells per testis showed an $84 \%$ increase in PTU-treated rats compared with controls (Table 2). However, the average volume of Leydig cells in PTU-treated rats was $25 \%$ lower than that of controls.

No significant differences were observed between control and PTU-treated groups for LH-stimulated secretion of testosterone, androstenedione, 17 $\alpha$-hydroxyprogesterone or progesterone (Fig. 4). Nevertheless, steroid secretion per Leydig cell was significantly lower in PTU-treated rats than in controls (Fig. 5).

\section{Discussion}

The study reported here demonstrates that transient neonatal hypothyroidism in rats causes pronounced changes in the number and volume of Leydig cells and volumes of other interstitial components, namely, blood vessels, connective tissue cells and the lymphatic space at maturity. These findings are consistent with observations that transient neonatal hypothyroidism causes an unprecedented increase in adult testis size and sperm production (Cooke et al., 1991 and 1992; Kirby $e$ t al., 1992). The magnitude of the increase in volumes of testis interstitium $(86 \%)$ and seminiferous tubules $(80 \%)$ is similar to the overall increase in testis volume in PTU-treated



Fig. 4. LH-stimulated steroid secretion per testis per hour of in vitro perfused testes of $(\square)$ control and ( $\square$ ) propylthiouracil (PTU)-treated rats. Testosterone (T), androstenedione (Androst), 17 $\alpha$-hydroxyprogesterone (17-OH-P) and progesterone (Prog) secretory capacity per testis is not significantly $(P>0.05)$ different between control and propylthiouracil (PTU)-treated rats.

rats $(84 \%)$, indicating that the unprecedented increase in testis size after PTU treatment results from equal increases in both the tubular and intertubular compartments of the testis. Nevertheless, different components of the testis interstitium showed different volume changes.

The volume of the lymphatic space showed the largest increase (approximately 2.5 -fold) of all components in the testis interstitium in the PTU-treated rats. This increase in lymphatic space following PTU treatment may be related to the increase in seminiferous tubule cross-sectional area and to the greater total number of Sertoli cells (Van Haaster et al., 1992; Hess et al., 1993). Because the treated Sertoli cells appear to function normally, their increase in number along the basement membrane would probably cause an increase in 


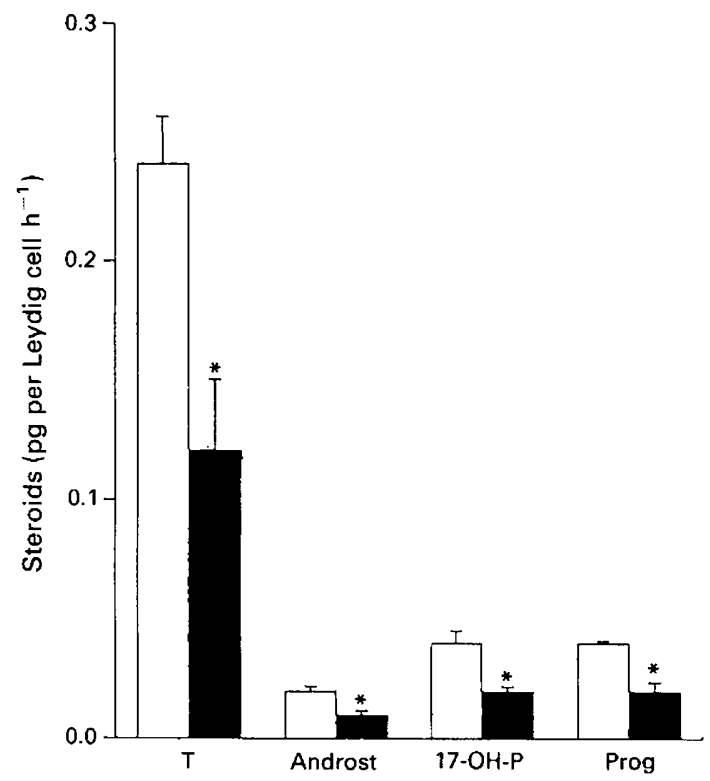

Fig. 5. LH-stimulated steroid secretion per Leydig cell per hour of ( $\square$ ) control and ( $\boldsymbol{\square})$ propylthiouracil (PTU)-treated rats. ${ }^{*}$ Testosterone (T), androstenedione (Androst), 17 $\alpha$-hydroxyprogesterone (17-OH-P) and progesterone (Prog) secretory capacity per Leydig cell is significantly greater $(P<0.05)$ in controls compared with PTU-treated rats.

the secretion of fluid both proluminally and into the interstitium. Hess et al. (1993) showed that on a Sertoli cell basis, abundance of mRNA for androgen binding protein (ABP) was similar in control and PTU-treated testes. Thus, if $20 \%$ of the ABP is secreted into the interstitium (Gunsalus et al., 1980) and there is an increased number of Sertoli cells, it is probable that there is an overall increase in the amount of fluid secreted by seminiferous tubules. Although the average volume of Leydig cells was lower to maintain normal concentrations of serum testosterone following PTU treatment, the testis appears to have responded to a greater number of Sertoli and germ cells by greater volumes of both the seminiferous tubules and the lymphatic system, possibly to accommodate an increase in fluid secretion.

The study reported here demonstrated for the first time a two-fold increase in the number of Leydig cells per testis in PTU-treated rats compared with that of controls. Increases in the number of Leydig cells were observed after chronic LH treatment (Christensen and Peacock, 1980). However, studies have shown that serum LH concentrations in PTU-treated rats were significantly lower than in controls (Kirby et al., 1992), showing that LH is not the cause of Leydig cell hyperplasia in the PTU-treated rat. Leydig cell hyperplasia was also observed in many instances of seminiferous tubule damage, such as in experimental cryptorchidism (MendisHandagama et al., 1990b). This situation in part could be explained by the presence of mitogenic activity in testicular interstitial fluid, which has been shown to increase after seminiferous tubule damage (Drummond et al., 1987). In the study reported here, we observed Leydig cell hyperplasia without any visible seminiferous tubule damage; testicular sperm production is increased by almost $140 \%$ in PTUtreated rats compared with controls (Cooke et al., 1991, 1992;
Kirby et al., 1992), which confirms this observation. Moreover, studies in vitro have shown that growth factors that are known to be produced in the testis in vivo can affect the proliferative activity of Leydig cells (Khan et al., 1992). It is not known whether the transient neonatal hypothyroidism increases the mitotic activity of testicular interstitial fluid or whether any growth factors could induce Leydig cell proliferation. However, it was shown that hypothyroidism causes proliferation of types of connective tissue cell such as fibroblasts, in the testis interstitium (Amin and El-Sheikh, 1977) in neonatal rats. It is therefore likely that in the present study the transient neonatal PTU treatment may have resulted in more Leydig cell precursors in prepubertal testes of PTU-treated rats than in controls. This situation may allow the PTU-treated rats to have significantly greater numbers of Leydig cells at maturity, because Leydig cells have been shown to differentiate from connective tissue cell precursors during development (Lording and de Kretser, 1972; Christensen, 1975), and after ethane dimethane sulfonate (EDS) treatment (Kerr et al., 1985; Jackson et al., 1986).

The presence of immature Leydig cells, which were very similar in morphology to fetal Leydig cells in the testis interstitium of PTU-treated rats, suggests that at least one mechanism for increasing the number of Leydig cells in PTU-treated rats may be similar to the differentiation pattern that is observed in fetal testes and the testes of EDS-treated rats, that is, differentiation of connective tissue cell precursors to Leydig cells via intermediate stages. Among different types of connective tissue cells in the testis interstitium, peritubular cells were also shown to be precursors of Leydig cells in several studies on pubertal maturation (de Kretser, 1967; Fawcett, 1973; Christensen, 1975; van Straaten and Wensing, 1978) as well as after EDS treatment (Kerr et al., 1985; Jackson et al., 1986). This contention is also supported by the observation that interstitial cells suggested to be Leydig cell precursors were noted within the peritubular tissue of human testes in cases of cryptorchidism (Mori et al., 1978). On the basis of these observations, it is believed that newly differentiated Leydig cells may arise at least partly from peritubular cells. They subsequently leave the lamina propria to gain access to the surrounding interstitial tissue. Observations of immature Leydig cells adjacent to the peritubular region in the PTUtreated rat testes in the study reported here support this view. However, the possibility cannot be ruled out that there is differentiation of other types of connective tissue cell in the testis interstitium into Leydig cells.

An increase in the number of Leydig cells could also occur as a result of division of existing Leydig cells, although the rate of proliferation is very low (Teerds et al., 1989). The occurrence of Leydig cell mitosis in mammalian testes ranges between 1 in 17500 (Mendis-Handagama, 1991) and 1 in 20000 (Christensen and Peacock, 1980), and it is believed that a mitotic figure in a Leydig cell lasts less than an hour (Christensen and Peacock, 1980). This explains why it is extremely difficult to observe Leydig cells in mitosis. However, it is possible to induce proliferation of Leydig cells in adult testes by treating rats daily with hCG, which results in a significant increase in the number of Leydig cells that have incorporated $\left[{ }^{3} \mathrm{H}\right]$ thymidine and the number of mitotic figures (Teerds et al., 1988). Although Leydig cells in mitosis were not 
observed in PTU-treated rats in this study, it is possible that proliferation of differentiated Leydig cells increases the number of Leydig cells in PTU-treated rats.

The study reported here clearly shows, for the first time, that the LH-stimulated secretion of testosterone as well as of other steroids (androstenedione, 17 $\alpha$-hydroxyprogesterone and progesterone) by the in vitro perfused testes of control and PTU-treated 135-day-old rats was the same, despite the fact that the testes of PTU-treated rats at this particular age contained twice the number of Leydig cells. These findings are consistent with the previous observations that testosterone concentrations in serum were not different in adult control and PTU-treated rats up to $\mathbf{1 8 0}$ days of age (Cooke and Meisami, 1991; Kirby et al., 1992). Although the total number of Leydig cells was almost double in PTU-treated rats compared with controls, these cells could not produce a twofold increase in steroid concentrations compared with controls. This observation suggests that individual Leydig cells in PTU-treated rats were less differentiated in secreting steroids than were the Leydig cells in controls. It is well known that thyroid hormone is essential for cellular differentiation (Guyton, 1991). However, although PTU-treated rats were hypothyroid during the neonatal-prepubertal peroid, they had normal thyroid hormone concentrations at maturity.

The average volume of Leydig cells has a positive and linear correlation with its testosterone secretion (Mendis-Handagama et al., 1988) and the observation of a substantial reduction in the average volume of Leydig cells is apparently the cause of the reduced steroid secretion. This finding is similar to the situation in Leydig cells in the experimentally cryptorchid mouse (Mendis-Handagama et al., 1990a), in which Leydig cell hyperplasia occurs together with hypotrophy. Moreover, Leydig cell hypotrophy of PTU-treated rats was associated with a reduced capacity of Leydig cells to secrete androgens, similar to observations with cryptorchid mouse Leydig cells (Mendis-Handagama et al., 1990a). The reduced volume of individual Leydig cells after PTU treatment may partly be explained by the lower concentration of LH in serum (Kirby $e t$ al., 1992), which could prevent these cells from reaching their normal size and maximal secretion. The exact cause of lower LH concentrations in serum of PTU-treated rats is not known. Since the total steroidogenic capacity of the testes is maintained following PTU treatment, it is clear that this is achieved via increasing the number of Leydig cells per testis and thereby acquiring a similar quantity of cytoplasmic organelles required for steroid biosynthesis. Since close relationships have been shown between testosterone secretion and some Leydig cell organelles such as the smooth endoplasmic reticulum (Zirkin $e t$ al., 1980; Mendis-Handagama et al., 1988) and peroxisomes (Mendis-Handagama et al., 1988), it would be appropriate to examine the organelle complement of both the control and PTU-treated rat Leydig cells to test this hypothesis.

The authors wish to acknowledge the guidance and enthusiasm of Dr L. L. Ewing, who initiated this study. Dr Ewing passed away before the completion of this study and was unable to see the final outcome; we dedicate this paper to his memory. We also wish to thank P. Cooke for providing the rat pups used in this study, and P. Cooke and R. Hess for their comments on this manuscript. Supported by NIH grant HD07204 to L. L. Ewing and Grant
R180101-08 from the College of Veterinary Medicine Center of Excellence for Livestock Diseases and Human Health, University of Tennessee.

\section{References}

Amin SO and El-Sheikh AS (1977) Pituitary-testicular function in hypothyroid male rats Acta Anatomica 98 121-129

Christensen AK (1975) Leydig cells. In Handbook of Physiology Vol 5 pp 57-94 Eds DW Hamilton and RO Greep. Williams and Wilkins, Baltimore

Christensen AK and Peacock KC (1980) Increase in Leydig cell numbers in testes of adult rats treated chronically with an excess of human chorionic gonadotrophin Biology of Reproduction 22 383-391

Cochran RC, Darney KJ and Ewing LL (1979) Measurement of testosterone with a high performance liquid chromatograph equipped with a flow-through ultraviolet spectrophotometer. Journal of Chromatography 173 349-355

Cooke PS and Meisami E (1991) Early hypothyroidism in rats causes increased adult testis and reproductive organ size but does not change testosterone levels Endocrinology 129 237-243

Cooke PS, Hess RA, Porcelli J and Meisami E. (1991) Increased sperm production in adult rats after transient neonatal hypothyroidism Endocrinology 129 244-248

Cooke PS, Porcelli J and Hess RA (1992) Induction of increased testis growth and sperm production in adult rats by neonatal administration of the goitrogen propylthiouracil (PTU): the critical period Biology of Reproduction 46 146-154

Cooke PS, Kirby JD and Porcelli J (1993) Increased testis growth and sperm production in adult rats following transient neonatal goitrogen treatment: optimization of the propylthiouracil (PTU) dosage and effects of methimazole (MMI) Journal of Reproduction and Fertility 97 493-499

Dawes C (1980) Biological Techniques for Transmission and Scanning Electron Microscopy. The Offset House, Burlington

de Kretser DM (1967) The fine structure of the testicular interstitial cells in men of normal androgen status Zeitschcrift fur Zellforschung und Mikroscopische Anatomie 80 594-609

Drummond AE, Risbridger GP, O'Leary PC and de Kretser DM (1987) Alterations in mitogenic and steroidogenic activities in rat testicular interstitia fluid after administration of ethane dimethane sulphonate journal of Reproduction and Fertility 83 141-147

Ewing LL, Brown B, Irby DC and Jardine I (1975) Testosterone and 5a-reduced androgen secretion by rabbit testes-epididymides perfused in vitro Endocrinology 96 610-617

Fawcett DW (1973) Observations on the organization of the interstitial tissue of the testis and on the occluding cell junctions in the seminiferous epithelium. In Advances in the Biosciences Vol $10 \mathrm{pp} 83-99 \mathrm{Ed}$. G Raspe. Pergamon Press, Oxford

Gunsalus GL, Musto NA and Bardin CW (1980) Bidirectional release of a Sertoli cell product, androgen binding protein, into the blood and seminiferous tubule. In Testicular Development, Structure and Function pp 291-297 Ed. A Steinberger and E Steinberger. Raven Press, New York

Guyton AC (1991) The thyroid metabolic hormones. In Textbook of Medical Physiology pp 831-841 Ed. AC Guyton. WB Saunders Company, Philadelphia

Hess RA, Cooke PS, Bunick D and Kirby JD (1993) Adult testicular enlargement induced by neonatal hypothyroidism is accompanied by significant increases in Sertoli and germ cell numbers Endocrinology 132 2607-2613

Jackson AE, O'Leary PO, Ayers MM and de Kretser DM (1986) The effects of ethane dimethane sulphonate (EDS) on rat Leydig cells Biology of Reproduction 35 425-437

Kerr JB, Donachie K and Rommerts FFG (1985) Selective destruction and regeneration of rat Leydig cells in vivo Cell and Tissue Research 242 145-156

Khan SK, Teerds K and Dorrington J (1992) Growth factor requirement for DNA synthesis by Leydig cells Biology of Reproduction 46 335-341

Kirby JD, Jetton AE, Cooke PS, Hess RA, Bunick D, Ackland JF, Turek FW and Schwartz NB (1992) Developmental hormonal profiles accompanying the neonatal hypothyroidism-induced increase in adult testicular size and sperm production in the rat Endocrinology 131 559-565

Lording DW and de Kretser DM (1972) Comparative ultrastructural and histochemical studies of the interstitial cells of the rat testis during fetal and postnatal development Journal of Reproduction and Fertility 29 261-269 
Mendis-Handagama SMLC (1991) Mitosis in normal adult guinea pig Leydig cells Joumal of Andrology 12 240-243

Mendis-Handagama SMLC (1992) Estimation error of Leydig cell numbers in atrophied rat testes due to the assumption of spherical nuclei Journal of Microscopy 168 25-32

Mendis-Handagama SMLC and Ewing LL (1990) Sources of error in the estimation of Leydig cell numbers in control and atrophied mammalian testes Journal of Microscopy 159 73-82

Mendis-Handagama SMLC, Risbridger GP and de Kretser DM (1987) A morphometric analysis of the components of the neonatal and adult rat testis interstitium International Journal of Andrology 10 523-5.34

Mendis-Handagama SMLC, Zirkin BR and Ewing LL (1988) Comparison of components of the testis interstitium with testosterone secretion in hamster, rat and guinea pig testes perfused in vitro American Journal of Anatomy 181 $12-22$

Mendis-Handagama SMLC, Kerr JB and de Kretser DM (1990a) Experimental cryptorchidism in the adult mouse: 1. Qualitative and quantitative light microscopic morphology Journal of Andrology 11 539-547

Mendis-Handagama SMLC, Kerr JB and de Kretser DM (1990b) Experimental cryptorchidism in the adult mouse: II. A hormonal study Journal of Andrology 11 548-554

Mori H, Shiraishi T and Matsumoto K (1978) Structure, cytochemistry, endocytic activity and immunoglobulin $(\mathrm{Fc})$ receptors of rat testicular interstitial-tissue macrophages American Journal of Anatomy 168 I-13
Sterio DC (1984) The unbiased estimation of number and size of arbitrary particles using the disector Journal of Microscopy 134 127-136

Teerds KJ, De Rooij DG, Rommerts FF and Wensing CJ (1988) The regulation of the proliferation and differentiation of rat Leydig cell precursor cells after EDS administration or daily hCG treatment Journal of Andrology 9 343-351

Teerds KJ, De Rooij DG, Rommerts FF, van der Tweel I and Wensing CJ (1989) Turnover time of Leydig cells and other interstitial cells in testes of adult rats Archives of Andrology 23 105-111

VanDemark NL and Ewing LL (1963) Factors affecting testicular metabolism and function. I. A simplified perfusion technique for short-term maintenance of rabbit testis Journal of Reproduction and Fertility 6 1-8

Van Haaster LH, De Jong FH, Docter R and De Rooij DG (1992) The effect of hypothyroidism on Sertoli cell proliferation and differentiation and hormone levels during testicular development in the rat Endocrinology 131 1574-1576 van Straaten HWM and Wensing CJG (1978) Leydig cell development in the testis of the pig Biology of Reproduction 18 86-93

Zirkin BR, Ewing LL, Kromann and Cochran RC (1980) Testosterone secretion by rat, rabbit, guinea pig, dog, and hamster testes perfused in vitro: correlation with Leydig cell ultrastructure Endocrinology 107 1867-1874 